\title{
Changes of oxygen isotope values of soil $P$ pools associated with changes in soil pH
}

\author{
Verena Pfahler ${ }^{1 *}{ }^{*}$, Andy Macdonald ${ }^{2}$, Andrew Mead ${ }^{3}$, Andrew C. Smith ${ }^{4}$, \\ Federica Tamburini ${ }^{5}$, Martin S. A. Blackwell ${ }^{1}$ \& Steven J. Granger ${ }^{1}$
}

Field data about the effect of soil $\mathrm{pH}$ on phosphorus $(\mathrm{P})$ cycling is limited. A promising tool to study $P$ cycling under field conditions is the ${ }^{18} \mathrm{O}:{ }^{16} \mathrm{O}$ ratio of phosphate $\left(\delta^{18} \mathrm{O}_{\mathrm{P}}\right)$. In this study we investigate whether the $\delta^{18} \mathrm{O}_{\mathrm{P}}$ can be used to elucidate the effect of soil pH on P cycling in grasslands. Soils and plants were sampled from different fertilisation and lime treatments of the Park Grass long term experiment at Rothamsted Research, UK. The soils were sequentially extracted to isolate different soil $P$ pools, including available $P$ and corresponding $\delta^{18} O_{P}$ values were determined. We did not observe changes in plant $\delta^{18} O_{P}$ value, but soil $P \delta^{18} O_{P}$ values changed, and lower $\delta^{18} O_{P}$ values were associated with higher soil $\mathrm{pH}$ values. At sites where $\mathrm{P}$ was not limiting, available $\mathrm{P} \delta^{18} \mathrm{O}_{\mathrm{P}}$ increased by up to $3 \%$ when lime was applied. We show that the $\delta^{18} \mathrm{O}_{P}$ method is a useful tool to investigate the effect of $\mathrm{pH}$ on soil $\mathrm{P}$ cycling under field conditions as it highlights that different soil processes must govern $\mathrm{P}$ availability as $\mathrm{pH}$ shifts. The next challenge is now to identify these underlying processes, enabling better management of soil $\mathrm{P}$ at different $\mathrm{pH}$.

Global food production relies on the use of phosphorus (P) fertilisers which are primarily derived from finite rock phosphate reserves, the supply of which is restricted by their geographic distribution and threatened by geopolitics ${ }^{1}$. Grasslands cover approximately $25 \%$ of the world's ice-free land mass and are important for sustaining the increasing global demand for meat ${ }^{2}$. It is widely recognised that grassland productivity is strongly influenced by nitrogen $(\mathrm{N})$ and $\mathrm{P}$ inputs ${ }^{3}$. The yield from agricultural grasslands is often increased through the application of inorganic $\mathrm{P}$ fertilisers, but excessive use of $\mathrm{P}$ fertilisers can lead to a soil $\mathrm{P}$ surplus ${ }^{4}$, and to detrimental environmental effects, especially on water quality. To meet the increasing agricultural demand in a sustainable way, we need to improve our understanding of $\mathrm{P}$ cycling in grassland soils.

Phosphorus solubility, and therefore its availability to plants, is influenced by soil biotic and abiotic processes, e.g. P uptake by microorganisms, the formation of organic $\mathrm{P}$ compounds, sorption onto hydrous oxides or clay silicates and precipitation of $\mathrm{P}$ minerals, all of which can reduce the availability of $\mathrm{P}$ to plants ${ }^{5,6}$. Plants, as well as microorganisms, can adapt to $\mathrm{P}$ limitation by increasing the internal use efficiency of $\mathrm{P}$ or by increasing $\mathrm{P}$ availability in the soil. This involves processes like replacing phospholipids by sulfo-galactolipids and exuding organic acids and phosphatases, respectively. Associations with mycorrhizal fungi are also a common strategy of plants to increase $\mathrm{P}$ availability. However, not all adaptations are understood and it is, for example, still unclear how microorganisms cope with $\mathrm{P}$ limitation and low soil $\mathrm{pH}$ at the same time $\mathrm{P}^{7} \mathrm{P}$ availability is often said to be highest around a neutral soil $\mathrm{pH}^{8}$. Below optimum $\mathrm{pH}$ values are a global problem due to soil acidification ${ }^{9,10}$ and could thus further challenge the sustainable intensification of agriculture. This $\mathrm{pH}$ optimum for $\mathrm{P}$ availability was questioned recently by Barrow ${ }^{11}$, citing only laboratory studies for the determination of the $\mathrm{pH}$ optimum. But as pointed out by Simonsson et al. ${ }^{12}$, the effect of liming on $\mathrm{P}$ cycling under field conditions cannot be predicted by laboratory-based studies. The Park Grass Continuous Hay experiment at Rothamsted Research (Harpenden, UK) is one of the few field experiments investigating the effect of soil $\mathrm{pH}$. Park Grass contains plots that have received different lime applications for over 100 years, resulting in soils with distinct $\mathrm{pH}$ values ${ }^{13}$. Based on data from Park Grass, the effect of soil $\mathrm{pH}$ on plant species diversity ${ }^{14}$ and the microbial abundance and community structure in

\footnotetext{
${ }^{1}$ Rothamsted Research, Sustainable Agriculture Sciences North Wyke, Okehampton, Devon, EX20 2SB, UK. ${ }^{2}$ Rothamsted Research, Sustainable Agriculture Sciences Harpenden, Harpenden, Hertfordshire, AL5 2JO, UK. ${ }^{3}$ Rothamsted Research, Computational and Analytical Sciences, Harpenden, Hertfordshire, AL5 2JQ, UK. ${ }^{4}$ NERC Isotope Geoscience Laboratory, British Geological Survey, Nottingham, NG12 5GG, UK. ${ }^{5}$ Department of Environmental System Sciences, ETH Zurich, Eschikon 33, 8315, Lindau, Switzerland. *email: v.pfahler@gmail.com
} 


\begin{tabular}{|l|l|l|l|l|l|l|l|}
\hline \multirow{4}{*}{ Treatment } & \multirow{2}{*}{ Soil pH } & \multicolumn{2}{l|}{ Total C (\% DW) } & \multicolumn{2}{l|}{ Total N (\% DW) } \\
\cline { 2 - 8 } & Depth $(\mathbf{c m})$ & $+\mathbf{L}$ & $-\mathbf{L}$ & $+\mathbf{L}$ & $-\mathbf{L}$ & $+\mathbf{L}$ & - L \\
\hline \multirow{4}{*}{$-\mathrm{N}+\mathrm{P}$} & $0-10$ & 6.40 & 4.37 & 5.08 & 3.81 & 0.49 & 0.34 \\
\cline { 2 - 8 } & $10-20$ & 5.91 & 4.26 & 3.71 & 2.67 & 0.37 & 0.23 \\
\cline { 2 - 8 } & $20-30$ & 6.14 & 4.49 & 1.70 & 1.35 & 0.21 & 0.16 \\
\hline \multirow{4}{*}{$+\mathrm{N}+\mathrm{P}$} & $0-10$ & 6.36 & 3.24 & 5.95 & 10.80 & 0.54 & 0.85 \\
\cline { 2 - 8 } & $10-20$ & 6.29 & 3.13 & 4.22 & 4.31 & 0.39 & 0.37 \\
\cline { 2 - 8 } & $20-30$ & 5.91 & 3.37 & 1.69 & 1.47 & 0.14 & 0.17 \\
\hline \multirow{3}{*}{$-\mathrm{N}-\mathrm{P}$} & $0-10$ & 6.52 & 4.49 & 4.95 & 4.69 & 0.45 & 0.42 \\
\cline { 2 - 8 } & $10-20$ & 5.98 & 4.35 & 3.21 & 2.73 & 0.34 & 0.28 \\
\cline { 2 - 8 } & $20-30$ & 5.95 & 4.74 & 1.60 & 1.33 & 0.19 & 0.18 \\
\hline
\end{tabular}

Table 1. Further soil characteristics of the sampled treatments. $+\mathrm{L}$ and $-\mathrm{L}=$ with or without addition of lime, respectively. $+\mathrm{N}$ and $-\mathrm{N}=$ with or without addition of nitrogen $(\mathrm{N})$ fertiliser. $+\mathrm{P}$ and $-\mathrm{P}=$ with or without addition of $\mathrm{P}$ fertiliser. Total $\mathrm{C}=$ total carbon. $\mathrm{DW}=$ dry weight.

the soil ${ }^{15}$ was shown. It is however challenging to identify the most important processes behind the effects of soil $\mathrm{pH}$ under field conditions due to the complexity of soil-microbe-plant interactions.

We investigated if the ${ }^{18} \mathrm{O}:{ }^{16} \mathrm{O}$ ratio of phosphate $\left(\delta^{18} \mathrm{O}_{\mathrm{P}}\right)$ of soil and plant $\mathrm{P}$ pools can be used to obtain new insights into how $\mathrm{P}$ cycling varies across $\mathrm{pH}$ gradients under field conditions. The basis of the ${ }^{18} \mathrm{O}_{\mathrm{p}}$ technique is that $\mathrm{P}$ is mainly associated with oxygen $(\mathrm{O})$ in the environment. Abiotic and biotic processes involving $\mathrm{P}$ can lead to isotopic fractionation, i.e. the enrichment or depletion of ${ }^{18} \mathrm{O}$ relative to ${ }^{16} \mathrm{O}$ in case of the $\delta^{18} \mathrm{O}_{\mathrm{p}}$. While the effect of abiotic processes in soils on the $\delta^{18} \mathrm{O}_{\mathrm{p}}$ seems to be negligible ${ }^{16-18}, \delta^{18} \mathrm{O}_{\mathrm{p}}$ signatures can be altered by biological processes. For example, a preference for the lighter phosphate isotopologue was observed for phosphate uptake by Escherichia coli, leaving the remaining phosphate enriched in ${ }^{18} \mathrm{O}^{19}$. Hydrolysing enzymes, which can be excreted by microorganisms and plants, can alter the $\delta^{18} \mathrm{O}_{\mathrm{P}}$ by cleaving the $\mathrm{P}$-O bond. Fractionation factors, i.e. the extent of isotopic fractionations, of such enzymatic processes are so far known for only a few enzymes involved in the $\mathrm{P}$ cycle, such as acid phosphatase $(-10 \%)^{20}$ and alkaline phosphatase $(-30 \%)^{21}$. The inorganic pyrophosphatase (PPase), an ubiquitous intracellular enzyme, leads to a temperature-dependent equilibrium between $\mathrm{O}$ in water and in phosphate ${ }^{22}$. The $\delta^{18} \mathrm{O}_{\mathrm{p}}$ values reported in the literature are often compared to this theoretical value, as it is considered to be an indication of $\mathrm{P}$ cycling through microorganisms $\mathrm{s}^{23}$.

We investigate if shifts in available $\mathrm{P} \delta^{18} \mathrm{O}_{\mathrm{P}}$ values in the soil are associated with changes in soil management strategies, particularly changes in $\mathrm{N}$ applications and soil $\mathrm{pH}$. We focus on available $\mathrm{P}$, because it is rapidly cycled within the soil and thus greatly influenced by processes like the hydrolysis of organic P. Less mobile P pools like the mineral $\mathrm{P}$ pool will not be associated with variations in soil $\mathrm{pH}$.

\section{Results}

Soil characteristics. The $+\mathrm{L}$ treatments always resulted in a higher $\mathrm{pH}$ than $-\mathrm{L}$ treatments (Table 1 ), with soil $\mathrm{pH}$ values as low as $3.13(+\mathrm{N}+\mathrm{P}-\mathrm{L}, 10-20 \mathrm{~cm})$. Soil $\mathrm{pH}$ did not vary with depth while both TC and TN concentrations decreased with depth. Total C ranged between 1.3 and $10.8 \%$ dry weight (DW) and TN ranged between 0.14 and $0.85 \%$ DW. The highest TC and TN concentrations occurred in the uppermost $10 \mathrm{~cm}$ of the soil profile and were highest in the $+\mathrm{N}+\mathrm{P}-\mathrm{L}$ plot (Table 1).

Phosphorus concentrations. The lime from the sample archive contained $0.5 \mathrm{mg} \mathrm{g} \mathrm{g}^{-1}$, meaning that the $+\mathrm{L}$ treatment receives a minimal $\mathrm{Pi}$ application and that the rate in 2015 was $1.75,1.25$, and $0.875 \mathrm{~kg} \mathrm{Pha}^{-1}$ for the $+\mathrm{N}+\mathrm{P}+\mathrm{L},-\mathrm{N}+\mathrm{P}+\mathrm{L}$, and $-\mathrm{N}-\mathrm{P}+\mathrm{L}$ treatment, respectively. Variation in $\mathrm{P}$ concentrations in the soil $\mathrm{P}$ pools, except residual $\mathrm{P}$, were associated with changes of depth and treatment (Table 2). Within each treatment, $\mathrm{P}$ concentrations of the different $\mathrm{P}$ pools declined with depth, with the exception of microbial $\mathrm{P}$ in the $+\mathrm{N}+\mathrm{P}$ treatments and the $-\mathrm{N}+\mathrm{P}-\mathrm{L}$ treatment (Table 2). Except for microbial and residual $\mathrm{P}$, the highest $\mathrm{P}$ concentrations were found in the $0-10 \mathrm{~cm}$ layer of the $+\mathrm{N}+\mathrm{P}$ treatments (Table 2). Microbial $\mathrm{P}$ concentration was highest in the $-\mathrm{N}-\mathrm{P}-\mathrm{L}$ treatment and residual $\mathrm{P}$ concentration was highest in the $-\mathrm{N}+\mathrm{P}+\mathrm{L}$ treatment. The lowest $\mathrm{P}$ concentrations, except for microbial and residual $\mathrm{P}$, were found in the $-\mathrm{N}-\mathrm{P}$ treatments. Microbial $\mathrm{P}$ concentrations were lowest in the fertilised treatments and residual P concentration was lowest in the $+\mathrm{N}+\mathrm{P}-\mathrm{L}$ treatment (Table 2).

Calculated equilibrium values. Soil temperatures ranged from 3.3 to $4.7^{\circ} \mathrm{C}$ in the $0-10 \mathrm{~cm}$ layer, 4.4 to $4.9^{\circ} \mathrm{C}$ in the $10-20 \mathrm{~cm}$ layer, and 4.8 to $5.1^{\circ} \mathrm{C}$ in the $20-30 \mathrm{~cm}$ layer in the 24 hours prior to soil sampling. The soil water $8^{18} \mathrm{O}_{\mathrm{H} 2 \mathrm{O}}$ ranged between -7.4 and $-5.3 \%$ (Table 3 ) and decreased with depth. The calculated equilibrium values ranged between 18.3 and $20.7 \%$ and did not show any marked variation across the treatments.

Oxygen isotope values of lime, vegetation, and soil phosphorus pools. The lime from the sample archive of Rothamsted Research had a $\delta^{18} \mathrm{O}_{P}$ of $14.7 \%$ (2007) and $18.0 \%$ (2013). The fertiliser $\delta^{18} \mathrm{O}_{P}$ was $20.6 \%$ (1986) and $18.6 \%$ (2012). The TCA P $\delta^{18} \mathrm{O}_{\mathrm{P}}$ of the vegetation ranged between 16.3 and $22.9 \%$ but was not associated with the application of lime (+L vs $-\mathrm{L}: 22.9$ vs $22.3 \% 0(-\mathrm{N}+\mathrm{P}), 22.3$ vs $21.2 \% 0(+\mathrm{N}+\mathrm{P})$, and $16.3 \mathrm{vs}$ $16.4 \% 0(-\mathrm{N}-\mathrm{P}))$. Similarly, the TCA P $\delta^{18} \mathrm{O}_{\mathrm{P}}$ was not associated with the application of $\mathrm{N}$ fertiliser $(-\mathrm{N}+\mathrm{P}$ 


\begin{tabular}{|c|c|c|c|c|c|c|c|c|c|c|c|c|c|c|c|}
\hline \multirow[b]{2}{*}{ Treatment } & \multirow[b]{2}{*}{ Depth $(\mathrm{cm})$} & \multicolumn{2}{|c|}{ Resin P } & \multicolumn{2}{|c|}{ Microbial P } & \multicolumn{2}{|c|}{ NaOH-EDTA Pi } & \multicolumn{2}{|c|}{ NaOH-EDTA $P_{\text {org }}$} & \multicolumn{2}{|c|}{ HCl P } & \multicolumn{2}{|c|}{ Residual P } & \multicolumn{2}{|l|}{ Total P } \\
\hline & & $+\mathrm{L}$ & $-\mathrm{L}$ & $+\mathrm{L}$ & $-\mathrm{L}$ & $+\mathrm{L}$ & $-\mathrm{L}$ & $+\mathrm{L}$ & $-\mathrm{L}$ & $+\mathrm{L}$ & $-\mathrm{L}$ & $+\mathrm{L}$ & $-\mathrm{L}$ & $+\mathrm{L}$ & $-\mathrm{L}$ \\
\hline \multirow{3}{*}{$-\mathrm{N}+\mathrm{P}$} & $0-10$ & 87.7 & 77.2 & 15.9 & 23.2 & 11.4 & 01.3 & 2.2 & 24.7 & 84.9 & 67.6 & $\underline{513.5}$ & 223.2 & 1825.6 & 1817.1 \\
\hline & $10-20$ & 46.9 & 54.8 & 11.3 & 0.0 & 710.1 & 2.5 & 356.7 & 265.2 & 61.2 & 28.3 & 287.0 & 217.6 & 1473.3 & 1278.3 \\
\hline & $20-30$ & \begin{tabular}{|l|l|}
18.1 \\
\end{tabular} & 11.2 & 0.0 & 6.9 & 290.2 & & & 96.0 & .7 & 5.7 & 346.2 & .5 & .1 & 555.4 \\
\hline \multirow{3}{*}{$+\mathrm{N}+\mathrm{P}$} & $0-10$ & 57.1 & $\underline{126.9}$ & 0.0 & 0.0 & 903.6 & $\underline{1170.3}$ & 382.5 & $\underline{495.8}$ & 98.1 & 90.4 & 247.5 & 231.8 & 1688.8 & $\underline{2115.2}$ \\
\hline & $10-20$ & 22.6 & 37.4 & 5.1 & 18.7 & 662.5 & 1108.7 & 359.5 & 336.8 & 44.9 & 36.9 & 221.1 & 110.8 & 1315.7 & 1649.2 \\
\hline & $20-30$ & 7.6 & 6.3 & 2.2 & 0.0 & 284.9 & 301.1 & 156.3 & & 15.8 & 11.9 & 298.9 & 342.8 & 765.7 & 780.9 \\
\hline \multirow{3}{*}{$-\mathrm{N}-\mathrm{P}$} & $0-10$ & 0.5 & 1.2 & 32.3 & $\underline{41.2}$ & 51.5 & 31.8 & 164.8 & 216.7 & 4.2 & 3.2 & 217.5 & 146.2 & 470.7 & \begin{tabular}{|l|l|}
440.4 \\
\end{tabular} \\
\hline & \begin{tabular}{|l|}
$10-20$ \\
\end{tabular} & 0.4 & 0.6 & 16.0 & \begin{tabular}{|l|}
19.0 \\
\end{tabular} & 37.4 & 28.0 & 159.3 & 163.3 & 3.7 & 1.7 & \begin{tabular}{|l|}
231.9 \\
\end{tabular} & \begin{tabular}{|l|}
183.9 \\
\end{tabular} & 4448.7 & 396.5 \\
\hline & \begin{tabular}{|l|}
$20-30$ \\
\end{tabular} & 0.3 & \begin{tabular}{|l|}
0.2 \\
\end{tabular} & 3.0 & 7.2 & 38.5 & 31.6 & 130.7 & 135.2 & 5.3 & 4.6 & \begin{tabular}{|l|}
173.5 \\
\end{tabular} & \begin{tabular}{|l|}
184.6 \\
\end{tabular} & 351.3 & \begin{tabular}{|l|}
363.4 \\
\end{tabular} \\
\hline
\end{tabular}

Table 2. Phosphorus concentrations ( $\mathrm{mg} \mathrm{P} \mathrm{kg}^{-1}$ soil) of different soil $\mathrm{P}$ pools extracted sequentially. $+\mathrm{L}$ and $-\mathrm{L}=$ with or without addition of lime, respectively. $+\mathrm{N}$ and $-\mathrm{N}=$ with or without addition of nitrogen $(\mathrm{N})$ fertiliser. $+\mathrm{P}$ and $-\mathrm{P}=$ with or without addition of $\mathrm{P}$ fertiliser. Bold numbers indicate the lowest concentrations for each $\mathrm{P}$ pool across treatments and depth, whereas underlined numbers indicate the highest concentrations.

\begin{tabular}{|c|c|c|c|c|c|c|c|c|c|c|c|c|c|}
\hline \multirow[b]{3}{*}{ Treatment } & \multirow[b]{3}{*}{ Depth $(\mathrm{cm})$} & & & \multicolumn{10}{|l|}{$\delta^{18} \mathrm{O}_{\mathrm{P}}(\% \mathrm{o})$} \\
\hline & & \multicolumn{2}{|c|}{ Soil water $\delta^{18} \mathrm{O}_{\mathrm{H} 2 \mathrm{O}}(\%)$} & \multicolumn{2}{|c|}{ Equilibrium range } & \multicolumn{2}{|c|}{ Resin P } & \multicolumn{2}{|c|}{ Hexanol P } & \multicolumn{2}{|c|}{ NaOH-EDTA Pi } & \multicolumn{2}{|c|}{ HCl P } \\
\hline & & $+\mathrm{L}$ & $-\mathbf{L}$ & $+\mathrm{L}$ & $-\mathrm{L}$ & $+\mathrm{L}$ & $-\mathbf{L}$ & $+\mathrm{L}$ & $-\mathbf{L}$ & $+\mathrm{L}$ & $-\mathbf{L}$ & $+\mathrm{L}$ & $-\mathbf{L}$ \\
\hline \multirow{3}{*}{$-\mathrm{N}+\mathrm{P}$} & $0-10$ & -5.9 & -5.6 & $19.8-20-0$ & $20.1-20.3$ & 20.0 & 23.0 & 18.3 & 21.7 & 15.2 & 17.6 & 21.7 & 22.7 \\
\hline & $10-20$ & -6.7 & -6.9 & $19.0-19.1$ & $18.8-18.9$ & 20.3 & 24.5 & 19.5 & 23.2 & nd & nd & 20.4 & 21.7 \\
\hline & $20-30$ & -6.6 & -6.4 & $19.0-19.1$ & $19.3-19.3$ & 19.7 & 21.9 & 18.4 & 21.8 & nd & nd & 19.0 & nd \\
\hline \multirow{3}{*}{$+\mathrm{N}+\mathrm{P}$} & $0-10$ & -5.5 & -5.3 & $20.2-20.4$ & $20.4-20.7$ & 18.7 & 21.9 & 17.9 & 22.1 & 20.7 & 17.4 & 18.5 & 22.2 \\
\hline & $10-20$ & -6.4 & -6.2 & $19.2-19.3$ & $19.5-19.6$ & 19.1 & 21.6 & 17.9 & 21.5 & nd & nd & 21.1 & 23.5 \\
\hline & $20-30$ & -7.4 & -6.2 & $18.3-18.3$ & $19.4-19.5$ & 18.9 & 21.2 & 17.6 & 23.6 & nd & nd & 20.9 & 23.9 \\
\hline \multirow{3}{*}{$-\mathrm{N}-\mathrm{P}$} & $0-10$ & -5.9 & -5.6 & $19.9-20.1$ & $20.1-20.4$ & nd & nd & 13.0 & 15.1 & nd & nd & nd & nd \\
\hline & $10-20$ & -7.1 & -6.9 & $18.5-18.6$ & $18.8-18.9$ & nd & nd & 14.0 & 14.1 & nd & nd & nd & nd \\
\hline & $20-30$ & -7.2 & -6.9 & $18.4-18.5$ & $18.7-18.8$ & nd & nd & nd & 15.4 & nd & nd & nd & nd \\
\hline
\end{tabular}

Table 3. Soil water $\delta^{18} \mathrm{O}_{\mathrm{H} 2 \mathrm{O}}$, equilibrium $\delta^{18} \mathrm{O}_{\mathrm{P}}$ range $\mathrm{e}^{\mathrm{a}}$, and resin and hexanol $\mathrm{P}, \mathrm{NaOH}-\mathrm{EDTA}$ inorganic $\mathrm{P}$ (Pi) and $\mathrm{HCl} \mathrm{P} \delta^{18} \mathrm{O}_{\mathrm{p}}$. The $\delta^{18} \mathrm{O}_{\mathrm{P}}$ values discussed within the manuscript are highlighted in bold text. nd $=$ not determined. $+\mathrm{L}$ and $-\mathrm{L}=$ with or without addition of lime, respectively. $+\mathrm{N}$ and $-\mathrm{N}=$ with or without addition of nitrogen $(\mathrm{N})$ fertiliser. $+\mathrm{P}$ and $-\mathrm{P}=$ with or without addition of $\mathrm{P}$ fertiliser. Contains Isotope Data, provided by the British Geological Survey, UKRI. ${ }^{a}$ Equilibrium range was calculated based on the minimum and maximum soil temperature during the 24-hour period before soil sampling for each depth: $3.3-4.7^{\circ} \mathrm{C}$ $(0-10 \mathrm{~cm}), 4.4-4.9^{\circ} \mathrm{C}(10-20 \mathrm{~cm})$, and $4.8-5.1^{\circ} \mathrm{C}(20-30 \mathrm{~cm})$.

vs $+\mathrm{N}+\mathrm{P}$ treatment; mean: 22.6 vs $21.8 \%$ ), however the $\delta^{18} \mathrm{O}_{\mathrm{P}}$ in the vegetation was lower in the $-\mathrm{N}-\mathrm{P}$ treatment (mean: $16.3 \%$ ).

The soil $\mathrm{P} \delta^{18} \mathrm{O}_{\mathrm{P}}$ values are presented in Table 3. Resin and $\mathrm{HCl} \mathrm{P}$ concentrations of the $-\mathrm{N}-\mathrm{P}-\mathrm{L}$ and $-\mathrm{N}-\mathrm{P}+\mathrm{L}$ treatments were too low for the determination of $\delta^{18} \mathrm{O}_{\mathrm{P}}$ values. The hexanol $\mathrm{P} \delta^{18} \mathrm{O}_{\mathrm{P}}$ values of the $-\mathrm{N}-\mathrm{P}$ treatments were less than the fertilised treatments (13.0 to $15.4 \%$ vs 17.6 to $23.6 \%$ ). The resin and hexanol $\mathrm{P} \delta^{18} \mathrm{O}_{\mathrm{P}}$ along with the concentrations of resin, microbial and hexanol $\mathrm{P}$, were used to determine microbial $\mathrm{P} \delta^{18} \mathrm{O}_{\mathrm{P}}$ values. However, for our data this approach is not straightforward. This is because the microbial $\mathrm{P}$ concentration has been calculated from a function of the resin $\mathrm{P}$ and the hexanol $\mathrm{P}$ (the latter always containing the former) and corrected for sorption onto the soil. For our soils either microbial P concentrations were almost negligible (fertilised treatments) or resin $\mathrm{P}$ concentrations were negligible $(-\mathrm{N}-\mathrm{P}-\mathrm{L}$ and $-\mathrm{N}-\mathrm{P}+\mathrm{L}$ treatments). Thus, correcting the hexanol $\mathrm{P} \delta^{18} \mathrm{O}_{\mathrm{P}}$ values could lead to misleading results.

For example, the resin and hexanol $\mathrm{P} \delta^{18} \mathrm{O}_{\mathrm{P}}$ values in the $10-20 \mathrm{~cm}$ layer of the $-\mathrm{N}+\mathrm{P}+\mathrm{L}$ treatment were very similar (20.3 vs $19.5 \%$ ). However, the calculated microbial $\mathrm{P} \delta^{18} \mathrm{O}_{\mathrm{P}}$ value, using resin and hexanol $\delta^{18} \mathrm{O}_{\mathrm{P}}$ values, would be $16.3 \%$. Given that the $0.8 \%$ difference between resin and hexanol $\delta^{18} \mathrm{O}_{\mathrm{P}}$ values could largely be accounted for by experimental noise we cannot be certain that the calculated microbial $\mathrm{P} \delta^{18} \mathrm{O}_{\mathrm{P}}$ is correct. Given this uncertainty, and that the contribution of microbial $\mathrm{P}$ is negligible within the fertilised treatments, we did not attempt to calculate microbial $\mathrm{P} \delta^{18} \mathrm{O}_{\mathrm{P}}$ from the hexanol $\mathrm{P} \delta^{18} \mathrm{O}_{\mathrm{p}}$. A similar issue occurred in the $-\mathrm{N}-\mathrm{P}$ treatments, whereby only low concentrations of resin $\mathrm{P}$ were measured as opposed to higher concentrations in the hexanol extraction. Rather than adjust the hexanol $\mathrm{P} \delta{ }^{18} \mathrm{O}_{\mathrm{P}}$ values, which would cause uncertainties, we assumed that the hexanol $\mathrm{P} \delta^{18} \mathrm{O}_{\mathrm{P}}$ data approximated the microbial $\mathrm{P} \delta^{18} \mathrm{O}_{\mathrm{P}}$ in the $-\mathrm{N}-\mathrm{P}$ treatments. Therefore, we will only discuss the resin $\mathrm{P} \delta^{18} \mathrm{O}_{\mathrm{P}}$ from the fertilised treatments and the hexanol $\mathrm{P} \delta^{18} \mathrm{O}_{\mathrm{P}}$ from the $-\mathrm{N}-\mathrm{P}$ treatments, acknowledging the caveats above.

Variations in resin, hexanol, and $\mathrm{HCl} \mathrm{P} \delta^{18} \mathrm{O}_{\mathrm{P}}$ were not associated with changes in depth within treatments, regardless of the changes in $\mathrm{P}$ concentrations with depth. In the fertilised treatments, resin $\mathrm{P} \delta^{18} \mathrm{O}_{\mathrm{P}}$ was higher 


\begin{tabular}{|c|c|c|c|c|c|c|}
\hline \multicolumn{2}{|c|}{ Treatment } & Equilibrium Range & TCA $P \delta^{18} O_{P}$ & $\operatorname{Resin} \mathrm{P} \delta^{18} \mathrm{O}_{\mathrm{P}}$ & Hexanol $\mathrm{P} \delta^{18} \mathrm{O}_{\mathrm{P}}$ & $\mathrm{HCl} P \delta^{18} \mathrm{O}_{\mathrm{P}}$ \\
\hline \multirow{2}{*}{$-\mathrm{N}+\mathrm{P}$} & $+\mathrm{L}$ & \multirow{6}{*}{18.3 to 20.7} & $22.9 \pm 0.9$ & $20.0 \pm 0.3$ & $n r$ & $20.4 \pm 1.4$ \\
\hline & $-\mathrm{L}$ & & $22.3 \pm 1.4$ & $23.1 \pm 1.3$ & $n r$ & $22.2 \pm 0.8$ \\
\hline \multirow{2}{*}{$+\mathrm{N}+\mathrm{P}$} & $+\mathrm{L}$ & & $22.3 \pm 0.4$ & $18.9 \pm 0.2$ & $n r$ & $20.2 \pm 1.5$ \\
\hline & $-\mathrm{L}$ & & $21.2 \pm 1.7$ & $21.6 \pm 0.4$ & $n r$ & $23.2 \pm 0.9$ \\
\hline \multirow{2}{*}{$-\mathrm{N}-\mathrm{P}$} & $+\mathrm{L}$ & & $16.3 \pm 0.3$ & nd & $13.5 \pm 0.7$ & nd \\
\hline & $-\mathrm{L}$ & & $16.4 \pm 0.6$ & $n d$ & $14.8 \pm 0.7$ & nd \\
\hline
\end{tabular}

Table 4. Resin, hexanol, and $\mathrm{HCl} P \delta^{18} \mathrm{O}_{\mathrm{P}}$ values (in \%o) expressed as mean over the three depths in each treatment and trichloroacetic acid soluble reactive (TCA) P $\delta^{18} \mathrm{O}_{\mathrm{P}}$ values (in \%o) of the vegetation. Contains Isotope Data, provided by the British Geological Survey, UKRI. Equilibrium range (in \%o) is the min and max equilibrium value across treatments and depth based on the min and max values of soil water $\delta^{18} \mathrm{O}$ and soil temperature of the 24 hours ahead of soil sampling. $+\mathrm{L}$ and $-\mathrm{L}=$ with or without addition of lime, respectively. $+\mathrm{N}$ and $-\mathrm{N}=$ with or without addition of nitrogen $(\mathrm{N})$ fertiliser. $+\mathrm{P}$ and $-\mathrm{P}=$ with or without addition of $\mathrm{P}$ fertiliser. $\mathrm{nr}=$ not relevant. $\mathrm{nd}=$ not determined.

in the $-\mathrm{L}$ treatments. This was not observed for the hexanol $\mathrm{P} \delta{ }^{18} \mathrm{O}_{\mathrm{P}}$ within the $-\mathrm{N}-\mathrm{P}$ treatments, but hexanol $\mathrm{P} \delta^{18} \mathrm{O}_{\mathrm{P}}$ was at least 5\%o lower than resin $\mathrm{P} \delta^{18} \mathrm{O}_{\mathrm{P}}$ in the fertilised treatments (Table 3). The $\mathrm{HCl} \mathrm{P} \delta^{18} \mathrm{O}_{\mathrm{P}}$ ranged between 18.5 and $23.9 \%$ and showed a similar trend to the resin $\mathrm{P} \delta{ }^{18} \mathrm{O}_{\mathrm{P}}\left(\delta^{18} \mathrm{O}_{\mathrm{P}}\right.$ values in the $+\mathrm{L}$ treatments less than those in the $-\mathrm{L}$ treatments). For the $0-10 \mathrm{~cm}$ soil samples in the fertilised treatments, where the $\mathrm{NaOH}-E D T A \mathrm{Pi} \delta^{18} \mathrm{O}_{\mathrm{P}}$ was measured, values ranged between 15.2 and $20.7 \%$. The $\mathrm{NaOH}-\mathrm{EDTA} \mathrm{Pi} \delta^{18} \mathrm{O}_{\mathrm{P}}$ were very similar in the $-\mathrm{L}$ fertilised treatments but differed between the $+\mathrm{L}$ treatments, with the $\mathrm{NaOH}$-EDTA Pi $\delta^{18} \mathrm{O}_{\mathrm{P}}$ in the $-\mathrm{N}+\mathrm{P}$ treatment being around $5 \%$ lower than in the $+\mathrm{N}+\mathrm{P}$ treatment. The NaOH-EDTA Pi $\delta^{18} \mathrm{O}_{\mathrm{P}}$ were different from the corresponding resin and $\mathrm{HCl} \mathrm{P} \delta^{18} \mathrm{O}_{\mathrm{P}}$, however while they were noticeably lower in most cases (up to $-6.5 \%$ ) the $\delta^{18} \mathrm{O}_{\mathrm{P}}$ value was higher (up to $2.2 \%$ ) in the $+\mathrm{N}+\mathrm{P}+\mathrm{L}$ treatment (Table 3 ).

\section{Discussion}

The relative proportions and distribution of the soil $\mathrm{P}$ pools within the soil profile were typical of those reported elsewhere ${ }^{24-26}$. In most cases all measured $\mathrm{P}$ pools decreased in concentration with depth. This reflects the accumulation of $\mathrm{P}$ in the upper layer in soils, through the adsorption of fertilizer to soil particles and through the accumulation of organic matter, and the low mobility of $\mathrm{P}^{27}$. Applying $\mathrm{N}$ fertiliser was associated with a small decrease in $\mathrm{P}$ concentrations as observed elsewhere ${ }^{28}$. The exception was the $0-10 \mathrm{~cm}$ layer of the $+\mathrm{N}+\mathrm{P}-\mathrm{L}$ treatment. In this treatment, a mat of partially decomposed plant material had developed, probably resulting from the effect of the very low soil $\mathrm{pH}$ on microbial activity and thus carbon cycling ${ }^{29}$. This organic matter rich layer was removed from the soil sample, but probably influenced $\mathrm{P}$ concentrations as indicated by our results (Table 2).

Higher $\mathrm{NaOH}$-EDTA Pi and $\mathrm{NaOH}-E D T A \mathrm{P}_{\text {org }}$, concentrations were associated with the application of fertiliser and in general the $\mathrm{NaOH}$-EDTA Pi pool was greater than the $\mathrm{NaOH}$-EDTA $\mathrm{P}_{\text {org }}$ pool within the fertilised treatments. This reflects the increased input of $\mathrm{P}$ to these systems, which is more readily stored as $\mathrm{NaOH}-\mathrm{EDTA}$ $\mathrm{Pi}$ than $\mathrm{HCl} \mathrm{P}$, as also indicated by the positive correlation between total $\mathrm{P}$ and $\mathrm{NaOH}-\mathrm{EDTA} \mathrm{Pi}\left(\mathrm{R}^{2}=0.96\right.$; data not shown). Changes in resin and microbial $\mathrm{P}$ concentrations as well as $\mathrm{NaOH}$-EDTA $\mathrm{P}_{\text {org }}$ concentrations were only slightly associated with the application of lime, but this did result in higher NaOH-EDTA Pi concentrations in the $+\mathrm{L}$ treatments mainly in the upper $10 \mathrm{~cm}$. This is somewhat surprising as liming increased organic $\mathrm{P}$ mineralisation in previous studies ${ }^{30,31}$, although more recent studies also found no or little effect of liming on organic $\mathrm{P}$ concentrations $\mathrm{s}^{12,32}$. The $+\mathrm{L}$ treatments always had slightly higher $\mathrm{HCl} \mathrm{P}$ concentrations compared to the $-\mathrm{L}$ treatments, which could be the result of the small Pi impurities in the lime. A concentration of $0.5 \mathrm{mg} \mathrm{P} \mathrm{g}^{-1}$ lime, as found in the samples we analysed, is not unusual ${ }^{33}$. The lower $\mathrm{HCl} \mathrm{P}$ concentrations in the $-\mathrm{L}$ treatments might also result from the increased solubility of $\mathrm{HCl} \mathrm{P}$, i.e. mineral $\mathrm{P}$ mainly, with decreasing $\mathrm{pH}$. Decomposition of plant material leads to the release of Pi (represented by TCA P in our study) to the soil. Plant TCA P can have distinct $\delta^{18} \mathrm{O}_{\mathrm{P}}$ values compared to soil $\mathrm{P}$ pools and leave an imprint on the $\delta^{18} \mathrm{O}_{\mathrm{P}}$ of soil $\mathrm{P}$ pools ${ }^{23}$. Changes in the TCA P $\delta^{18} \mathrm{O}_{\mathrm{P}}$ of the vegetation was not associated with the application of lime or $\mathrm{N}$ within the treatments and therefore seems to represent an impact of $\mathrm{P}$ fertilisation. This decrease in TCA P $\delta^{18} \mathrm{O}_{\mathrm{P}}$ values from the $\mathrm{P}$ fertilised treatments $(-\mathrm{N}+\mathrm{P}-\mathrm{L},-\mathrm{N}+\mathrm{P}+\mathrm{L},+\mathrm{N}+\mathrm{P}-\mathrm{L}$, and $+\mathrm{N}+\mathrm{P}+\mathrm{L} ; 21.2-22.9 \%$ ) relative to the control (16.3$16.4 \%$ ) is most likely caused by an increase in leaf acid phosphatase activity in the control, which hydrolyses organic $\mathrm{P}$ within the leaves producing ${ }^{18} \mathrm{O}$ depleted $\mathrm{Pi}$, which then becomes part of the TCA $\mathrm{P}^{34}$.

The $\delta^{18} \mathrm{O}_{\mathrm{P}}$ of the soil $\mathrm{P}$ pools varied little with depth (Table 3 ). This contrasts with the $\mathrm{P}$ concentrations and soil water $\delta^{18} \mathrm{O}_{\mathrm{H} 2 \mathrm{O}}$ values, which show a depth profile. Soil temperatures were low (around $4^{\circ} \mathrm{C}$ ) at the time of sampling and might have impacted biological activity and mineralization rates. As biological activity is considered a main driver of changes in $\delta^{18} \mathrm{O}_{\mathrm{P}}$ values, this could explain the lack of a depth gradient. As the $\delta^{18} \mathrm{O}_{\mathrm{P}}$ was not associated with changes of the sampling depth within the soil profile, the mean of the three depth values are used in the further discussion (Table 4). Hexanol $\mathrm{P} \delta^{18} \mathrm{O}_{\mathrm{P}}$ values for the fertilised treatments are not given in Table 4 as they are not relevant for the discussion.

Hexanol $\mathrm{P} \delta^{18} \mathrm{O}_{\mathrm{p}}$ from the $-\mathrm{N}-\mathrm{P}$ treatments (an approximation for microbial $\mathrm{P}$; mean 13.5 and $14.8 \%$, $+\mathrm{L}$ and $-\mathrm{L}$ respectively) were between 3.4 and $7.2 \%$ lower than equilibrium, and lower than any other $\delta^{18} \mathrm{O}_{\mathrm{P}}$ values in our study. Microbial $\mathrm{P} \delta^{18} \mathrm{O}_{\mathrm{P}}$ values, approximated in our study by hexanol $\mathrm{P} \delta^{18} \mathrm{O}_{\mathrm{P}}$ values, were also lower than the equilibrium shown in other cases $^{35}$. Under P limitation, other intracellular processes, like the hydrolysis of organic P, could partly disturb the equilibrium inside microorganisms as observed in plants ${ }^{36}$. Assuming an 
organic $\mathrm{P} \delta^{18} \mathrm{O}_{\mathrm{P}}$ between 12.7 and $27 \% \mathrm{o}^{37}$ and a soil water $\delta^{18} \mathrm{O}$ of $-6.4 \%$, Pi released by acid or alkaline phosphatases would have a $\delta^{18} \mathrm{O}_{\mathrm{P}}$ between 0.4 and $16.2 \%$, depending on the enzyme. Therefore, an increase in enzymatic organic $\mathrm{P}$ hydrolysis might have caused the below equilibrium hexanol $\mathrm{P} \delta^{18} \mathrm{O}_{\mathrm{P}}$ values.

Resin $\mathrm{P} \delta{ }^{18} \mathrm{O}_{\mathrm{P}}$ values in the fertilised treatments were at or greater (approximately $3 \%$ ) than the equilibrium. This could be caused by the contribution of a $\mathrm{P}$ source, more enriched in ${ }^{18} \mathrm{O}$, or by a preferential uptake of the lighter Pi isotopologue by plants and/or microorganisms. However, it is questionable whether the effect of $\mathrm{P}$ uptake can be observed in soils, as a soil is usually a well buffered system, i.e. the resin P pool is constantly replenished from other soil $\mathrm{P}$ pools (mainly). It is more likely that greater than equilibrium $\delta^{18} \mathrm{O}_{\mathrm{P}}$ values were caused by the contribution of a $\mathrm{P}$ source more enriched in ${ }^{18} \mathrm{O}$ such as TCA $\mathrm{P}$ in the vegetation.

The application of $\mathrm{N}$ fertiliser was associated with a small decrease in resin $\mathrm{P} \delta^{18} \mathrm{O}_{\mathrm{P}}$ values and only slightly decreased the $\mathrm{HCl} \mathrm{P} \delta^{18} \mathrm{O}_{\mathrm{P}}$ with very similar values in the case of the $-\mathrm{N}+\mathrm{P}+\mathrm{L}(20.4 \%$ o $)$ and $+\mathrm{N}+\mathrm{P}+\mathrm{L}$ (20.2\%o) plots (Table 4). Contrary to this, the $\mathrm{NaOH}$-EDTA Pi $\delta^{18} \mathrm{O}_{\mathrm{P}}$ only seemed to be associated with $\mathrm{N}$ fertilisation in $-\mathrm{L}$ treatments. This indicates that $\mathrm{HCl} \mathrm{P}$ and $\mathrm{NaOH}$-EDTA $\mathrm{Pi} \delta^{18} \mathrm{O}_{\mathrm{P}}$ values are influenced by processes different to those that effect the resin $\mathrm{P} \delta^{18} \mathrm{O}_{\mathrm{p}}$. However, the isotopic differences caused by $\mathrm{N}$ fertilisation are very small ( $<2 \%$; Table 4 ). This is in line with other studies which report also only minor effects of $\mathrm{N}$ fertilisation ${ }^{28}$. The lack of an $\mathrm{N}$ fertilisation effect on the $\delta^{18} \mathrm{O}_{\mathrm{P}}$ was attributed to the fact that $\mathrm{N}$ limitation enhances intracellular $\mathrm{P}$ cycling, which should lead to $\delta^{18} \mathrm{O}_{\mathrm{P}}$ values at or close to equilibrium. At the same time $\mathrm{N}$ limitation reduces the activity of hydrolysing enzymes, which may drive the $\delta^{18} \mathrm{O}_{\mathrm{P}}$ values further from expected equilibrium.

Changes in the soil $\mathrm{P} \delta^{18} \mathrm{O}_{\mathrm{p}}$ values of the treatments tested (Tables 2 and 3) were mainly associated with the application of lime, with $+\mathrm{L}$ treatments being approximately $3 \%$ lower than $-\mathrm{L}$. The lime had small Pi impurities $\left(0.5 \mathrm{mg} \mathrm{P} \mathrm{g}^{-1}\right)$ which had $\delta^{18} \mathrm{O}_{\mathrm{P}}$ values of 14.7 (2007) and 18.0 (2013) \% . This however, should not be a confounding issue as applied $\mathrm{P}$ sources are unlikely to be directly reflected in the resin $\mathrm{P} \delta^{18} \mathrm{O}_{\mathrm{P}}$ as the time between sampling and application was about one in year in our study ${ }^{38}$. It is more likely that the resin $\mathrm{P} \delta^{18} \mathrm{O}_{\mathrm{P}}$ values in the $+\mathrm{L}$ and $-\mathrm{L}$ treatments differ due to differences in $\mathrm{P}$ cycling between those treatments. This is also supported by the hexanol $\mathrm{P} \delta{ }^{18} \mathrm{O}_{\mathrm{P}}$ values, which show a similar pattern as resin $\mathrm{P} \delta{ }^{18} \mathrm{O}_{\mathrm{P}}$ indicating that microbial $\mathrm{P}$ cycling was also affected by soil $\mathrm{pH}$. As the TCA P $\delta^{18} \mathrm{O}_{\mathrm{P}}$ values of the vegetation were not associated with differences inliming, it is unlikely that the higher resin $\mathrm{P} \delta^{18} \mathrm{O}_{\mathrm{P}}$ values in the $-\mathrm{L}$ fertilised treatments were caused by the contribution of vegetation $\mathrm{P}$ directly. Abiotic processes, like the dissolution of minerals, could have influenced the resin $\mathrm{P} \delta^{18} \mathrm{O}_{\mathrm{P}}$ if the Pi had a distinctly different $\delta^{18} \mathrm{O}_{\mathrm{P}}$ value compared to the resin P. Additionally, the contribution of this abiotically released $\mathrm{Pi}$ to the resin $\mathrm{P}$ pool has to be relatively high compared to the contribution of biotic processes. This seems rather unlikely in the case of Park Grass because $\mathrm{HCl} \mathrm{P}$ concentrations are low and the soil $\mathrm{pH}$ is unfavourable for the desorption of Pi from oxides ${ }^{39,40}$. Furthermore, NaOH-EDTA Pi $\delta^{18} \mathrm{O}_{\mathrm{P}}$ in the $+\mathrm{N}+\mathrm{P}+\mathrm{L}$ treatment is enriched in ${ }^{18} \mathrm{O}$ compared to the $+\mathrm{N}+\mathrm{P}-\mathrm{L}$ treatment, whereas the opposite is the case for resin $\mathrm{P} \delta^{18} \mathrm{O}_{\mathrm{P}}$. This implies that the shift in resin $\mathrm{P} \delta{ }^{18} \mathrm{O}_{\mathrm{P}}$ between the $+\mathrm{N}+\mathrm{P}+\mathrm{L}$ and $+\mathrm{N}+\mathrm{P}-\mathrm{L}$ treatment is most likely due to biotic processes like enzymatic hydrolysis and not due to abiotic processes. Lime $\mathrm{P} \delta^{18} \mathrm{O}_{\mathrm{P}}$ values could potentially impact $\mathrm{HCl} \mathrm{P} \delta^{18} \mathrm{O}_{P}$, as these two pools are more stable than resin and microbial $\mathrm{P}$. The $\mathrm{HCl} \mathrm{P} \delta^{18} \mathrm{O}_{\mathrm{P}}$ values, as well as $\mathrm{HCl} \mathrm{P}$ concentrations, are higher in the $-\mathrm{L}$ treatments compared to the $+\mathrm{L}$ treatments. Based on a simple mass balance, using the $\delta^{18} \mathrm{O}_{\mathrm{P}}$ values of the lime and the $\mathrm{HCl} \mathrm{P}$ of the $-\mathrm{L}$ treatments, the $\mathrm{P}$ impurities in the lime could explain the decrease in $\mathrm{HCl} \mathrm{P} \delta^{18} \mathrm{O}_{\mathrm{P}}$ values from the $-\mathrm{L}$ to $+\mathrm{L}$ treatments. But the $\mathrm{HCl} \mathrm{P} \delta^{18} \mathrm{O}_{\mathrm{P}}$ values are also within the reported $\delta^{18} \mathrm{O}_{\mathrm{P}}$ range for sedimentary rocks $\left(12-21 \%{ }^{41}\right.$, the applied fertiliser $(18.6$ and $20.6 \%$ for the two fertiliser samples analysed in this study, but other fertiliser samples from the Rothamsted Sample Archive had $\delta^{18} \mathrm{O}_{\mathrm{P}}$ values up to $22.9 \%$ (A. C. Smith, personal communication)), and the TCA and resin $\mathrm{P} \delta^{18} \mathrm{O}_{\mathrm{P}}$ values. The similarity of the values makes it difficult to disentangle the origin of the $\mathrm{HCl} \mathrm{P}$ based on $\delta^{18} \mathrm{O}_{\mathrm{P}}$. It is, however, striking that we observe the same trends in the $\mathrm{HCl} \mathrm{P} \delta^{18} \mathrm{O}_{\mathrm{P}}$ values as for the resin $\mathrm{P}$ within the same treatments. This indicates that $\mathrm{HCl} \mathrm{P}$ could be an important component of P cycling in the Park Grass soil system and it is likely there is a continuous exchange between resin and $\mathrm{HCl} \mathrm{P}$ via the dissolution and formation of secondary $\mathrm{P}$ minerals ${ }^{42,43}$.

\section{Conclusions}

Even in a complex system like the one in Park Grass, changes in soil management were associated with changes in $\delta^{18} \mathrm{O}_{\mathrm{P}}$ values. Those changes in $\delta^{18} \mathrm{O}_{\mathrm{P}}$ values indicate that the processes involved in $\mathrm{P}$ cycling vary depending on the application of lime. Neither soil depth nor nitrogen fertiliser application were as strongly associated with changes in $\delta^{18} \mathrm{O}_{\mathrm{P}}$ values as liming. What caused those shifts remains unclear and needs further investigation. However, we have showed that the $\delta^{18} \mathrm{O}_{\mathrm{P}}$ can be used to study the effect of soil management on $\mathrm{P}$ cycling under field conditions. Withholding $\mathrm{P}$ fertiliser also had an impact on soil $\mathrm{P} \delta^{18} \mathrm{O}_{\mathrm{P}}$ values, however, our data is not sufficient to draw solid conclusions about the effect of $\mathrm{P}$ limitation on soil $\mathrm{P} \delta^{18} \mathrm{O}_{\mathrm{P}}$ values.

\section{Methods}

Site description. The Park Grass Continuous Hay experiment was established by John Lawes and Henry Gilbert at Rothamsted (Harpenden, Herts, UK) in 1856. It was established on a site which had been in permanent pasture for at least 100 years before the experiment began ${ }^{44}$. It was started to test the effects of different combinations of mineral fertilisers and organic manures on the productivity of permanent grassland cut for hay. The treatments include, an unfertilised control against which different amounts and combinations of mineral fertil-

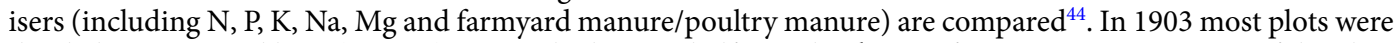
divided into two and lime $\left(\mathrm{CaCO}_{3}\right)$ was applied to one half at $4 \mathrm{t} \mathrm{ha}^{-1}$ every four years. In 1965 most of the plots were divided further into four sub-plots, which now receive lime every third year to maintain soil $\mathrm{pH}$ at 7 (subplot 'a'), 6 (sub-plot 'b'), and 5 (sub-plot 'c'), respectively. The fourth sub-plot ('d') does not receive lime and its $\mathrm{pH}$ varies depending on the treatment but is usually around $\mathrm{pH} 4$ or 5 . The soil is a chromic luvisol (FAO), referred to locally as a Stagnogleyic paleo-argillic brown earth of the Batcombe series ${ }^{45}$. 


\begin{tabular}{|c|c|c|c|c|c|c|}
\hline Referred to in text & Plot & Sub-plot & Nitrogen fertiliser $\left(\mathrm{kg} \mathrm{ha}^{-1} \mathrm{yr}^{-1}\right)$ & Other fertilisers $\left(\mathrm{kg} \mathrm{ha}^{-1} \mathrm{yr}^{-1}\right)$ & Lime $\left(\mathrm{tha}^{-1}\right)$ & Dominant plant species in $2000^{a}$ \\
\hline$-\mathrm{N}+\mathrm{P}+\mathrm{L}$ & $7 / 2$ & $\mathrm{a}$ & - & \multirow{4}{*}{$\begin{array}{l}\text { Triple superphosphate } \\
\text { (35); potassium sulphate } \\
(225) \text {; sodium sulphate }(15) \text {; } \\
\text { magnesium sulphate }(10)\end{array}$} & 2.5 & $\begin{array}{l}\text { Poa trivialis }(12.8 \%), \text { Lathyrus pratensis }(15.2 \%), \\
\text { Trifolium pratense }(10.5 \%) ; \mathrm{Sp}=23\end{array}$ \\
\hline$-\mathrm{N}+\mathrm{P}-\mathrm{L}$ & $7 / 2$ & $\mathrm{~d}$ & - & & - & Festuca rubra (17.5\%), Agrostis capillaris (48.3\%); $\mathrm{Sp}=21$ \\
\hline$+\mathrm{N}+\mathrm{P}+\mathrm{L}$ & $11 / 1$ & $\mathrm{a}$ & \multirow{2}{*}{ Ammonium sulphate (144) } & & 3.5 & $\begin{array}{l}\text { Poa trivialis }(46.5 \%), \text { Holcus lanatus }(15.6 \%) \\
\text { Arrhenatherum elatius (15.1\%); } \mathrm{Sp}=10\end{array}$ \\
\hline$+\mathrm{N}+\mathrm{P}-\mathrm{L}$ & $11 / 1$ & d & & & - & Holcus lanatus $(99.8 \%) ; \mathrm{Sp}=2$ \\
\hline$-\mathrm{N}-\mathrm{P}+\mathrm{L}$ & 12 & a & - & - & 1.75 & $\begin{array}{l}\text { Plantago lanceolate (11.4\%), Leontodon hispidus }(17.1 \%), \\
\text { Briza media (14.6\%), Lotus corniculatus (10.1\%); } \mathrm{Sp}=30\end{array}$ \\
\hline$-\mathrm{N}-\mathrm{P}-\mathrm{L}$ & 12 & d & - & - & - & $\begin{array}{l}\text { Festuca rubra (22.0\%), Agrostis capillaris (31.9\%), } \\
\text { Leontodon hispidus (16.0\%); } \mathrm{Sp}=22\end{array}$ \\
\hline
\end{tabular}

Table 5. Treatments of Park Grass analysed in this study including the dominant plant species (percentage $>10 \%$ ) and the total number of species (Sp) (data from 2000 and obtained from the electronic Rothamsted Archive).

$+\mathrm{L}$ and $-\mathrm{L}=$ with or without addition of lime, respectively. $+\mathrm{N}$ and $-\mathrm{N}=$ with or without addition of nitrogen $(\mathrm{N})$ fertiliser. $+\mathrm{P}$ and $-\mathrm{P}=$ with or without addition of $\mathrm{P}$ fertiliser. ${ }^{\mathrm{a}}$ This is the most recent data available for our selected treatments. A more recent survey of the "d" subplots showed that the dominant species in the d subplots in 2010-2012 are very similar as they were in 1991-2000 (Table 5 in Rothamsted Long-term Experiments ${ }^{13}$.

Having been designed before the pioneering research of R.A. Fisher at Rothamsted in the early 1900s, the Park Grass Experiment does not have the key statistical properties of replication and randomisation that are needed for most formal statistical analyses of data from designed experiments. Additional constraints in this study meant that samples could be collected and processed for only 6 plots with soil samples then obtained for three separate depths. Any formal statistical analysis would have to make very strong assumptions about the sources of variation, for example assessing the variation due to the main effects of the factors (fertiliser treatment, liming, depth) against the variation due to interactions amongst these factors. Any such analyses would also have low power to detect differences as statistically significant. As the aim of the study was to demonstrate the potential of the oxygen isotope ratio methodology to detect variation in $\mathrm{P}$ cycling responses under a range of fertiliser and $\mathrm{pH}$ conditions, rather than to test for differences due to these treatments, no formal statistical analysis has been performed, with observed values for the 18 treatment combinations presented to demonstrate patterns of response associated with changes in the soil system, and stimulate further study using this methodology.

Sampling and sample preparation. Our aim was to obtain a wide range of soil $\mathrm{pH}$ values. We therefore included treatments with triple superphosphate and either with or without application of ammonium sulphate (plots 11/1 (referred to hereafter as " $+\mathrm{N}+\mathrm{P}$ ") and 7/2 (referred to hereafter as " $-\mathrm{N}+\mathrm{P}$ ")) and an unfertilised control (plot 12; referred to hereafter as “-N-P") (Table 5). Within each of the three selected treatments, soil samples were taken from the 'a' and 'd' sub-plots. Sub-plot 'a', which received lime to maintain soil at pH 7, is referred to as ' $+\mathrm{L}$ ' and sub-plot 'd', which never receives lime as ' $-\mathrm{L}$ ' hereafter. Lime is applied every third year and was last applied in February 2015. Sampling took place on 1 March 2016, about one and a half months before application of $\mathrm{N}$ fertiliser (applied 19.4.2016) but about three months after the application of the other fertilisers including P fertiliser (applied 02.12.2015) (Table 5).

A mat of partially decomposed plant material had developed as a result of the low soil $\mathrm{pH}$ on the surface of the $+\mathrm{N}+\mathrm{P}-\mathrm{L}$ treatment. This mat was removed prior to soil sampling. From each of the selected treatments, 18 soil cores were taken by hand in a W-sampling pattern to a depth of $30 \mathrm{~cm}$ using a soil corer (internal diameter $2 \mathrm{~cm}$ ). The cores were divided into three depths: $0-10 \mathrm{~cm}, 10-20 \mathrm{~cm}$, and $20-30 \mathrm{~cm}$. They were bulked to give one sample per depth; a total of three samples per plot. The fresh soil samples were immediately sieved $<2 \mathrm{~mm}$, removing large stones, visible plant material and soil fauna and ensuring complete mixing. Three subsamples were taken from each sieved and fresh soil sample: (1) approximately $10 \mathrm{~g}$ for extraction of soil water, stored in tightly closed vacutainers at $-20^{\circ} \mathrm{C}$, (2) approximately $50 \mathrm{~g}$ for soil moisture content, dried at $105^{\circ} \mathrm{C}$ for 24 hours; (3) approximately $10 \mathrm{~g}$ for the determination of soil $\mathrm{pH}$, total carbon $(\mathrm{C})$, nitrogen $(\mathrm{N})$ and $\mathrm{P}$, air-dried, milled and sieved $<2 \mathrm{~mm}$. The remaining sample was stored at $4{ }^{\circ} \mathrm{C}$ prior to extraction of resin and hexanol $\mathrm{P}$ for $\delta^{18} \mathrm{O}_{\mathrm{P}}$. For the aboveground vegetation samples, vegetation was cut at ground level with scissors from the same locations as the soil cores and bulked per plot, giving six vegetation samples in total. From each sample, a small subsample (approximately $2 \mathrm{~g}$ ) was stored in a tightly closed vacutainer at $-20^{\circ} \mathrm{C}$ for the extraction of plant water. The remaining vegetation samples were stored in plastic bags at $-20^{\circ} \mathrm{C}$. Soil temperatures were obtained from the electronic Rothamsted archive (e-RA) of Rothamsted Research. The meteorological station is approximately $1 \mathrm{~km}$ from Park Grass. Soil temperatures are measured by Rothamsted Research hourly at a depth of 10, 20 and $30 \mathrm{~cm}$ in soil under grass.

Phosphorus in plants, lime and soil. Inorganic $\mathrm{P}(\mathrm{Pi})$ from the frozen plant material was extracted with $0.3 \mathrm{M}$ trichloroacetic acid (TCA) as described by Pfahler et al. ${ }^{36}$ and is afterwards referred to as TCA P. The most recently available lime samples (from 2007 and 2013) and fertiliser samples (from 1986 and 2012) from the Rothamsted Sample Archive were extracted with $1 \mathrm{M} \mathrm{HCl}$, as described below for the soil. The following soil $\mathrm{P}$ pools were extracted: resin, microbial, $\mathrm{NaOH}$-EDTA $\mathrm{P}_{\mathrm{i}}, \mathrm{NaOH}-\mathrm{EDTA} \mathrm{P}_{\text {org }}, \mathrm{HCl} \mathrm{P}$, and residual P. The availability of those pools decreases from resin to residual P. Resin and microbial $\mathrm{P}$ are considered the most labile pools, which can turnover within minutes to weeks, whereas turnover rates of $\mathrm{HCl} \mathrm{P}$ are estimated to be in the order of years or even millennia ${ }^{35}$. Within two weeks of sampling, resin, an approximation for available $\mathrm{P}$, and microbial $\mathrm{P}$ were extracted from fresh soil with anion exchange membranes, conditioned with bicarbonate, 
with or without the addition of hexanol ${ }^{46}$. For resin $\mathrm{P} 100 \mathrm{~g}$ of fresh soil, and 4 resin strips $(12.5 \times 12.5 \mathrm{~cm})$ were shaken for 16 hours at $4{ }^{\circ} \mathrm{C}$ in $5 \mathrm{~L}$ ultra-pure water $\left(\mathrm{ddH}_{2} \mathrm{O}\right)^{47}$. For microbial $\mathrm{P}$, the process was the same but with the addition of $30 \mathrm{ml}$ of hexanol. The recovered resin strips were washed thoroughly with $\mathrm{ddH}_{2} \mathrm{O}$ to remove any attached soil particles. The resin strips were eluted by shaking overnight in $75 \mathrm{~mL}$ of $0.2 \mathrm{M} \mathrm{HNO}_{3}$. As the soil to solution ratios in this extraction were elevated to enable sufficient $P$ to be collected for analysis, a separate sequential extraction was conducted for subsequent pools using the more conventional soil to solution ratio of $1: 10^{48}$. Microbial $\mathrm{P}$ was extracted again from $30 \mathrm{~g}$ soil (dry weight equivalent) before the soil was sequentially extracted with $0.25 \mathrm{M} \mathrm{NaOH}-0.05 \mathrm{M}$ EDTA, targeting oxide bound inorganic and organic $\mathrm{P}$, and $1 \mathrm{M} \mathrm{HCl}$, targeting mineral P. To account for any hydrolysis of organic $\mathrm{P}$ or polyphosphates during the $1 \mathrm{M} \mathrm{HCl} \mathrm{step,}{ }^{18} \mathrm{O}$-labelled (three batches: $\delta^{18} \mathrm{O}$ value of $46.1 \%, 14.2 \%$, and $22.4 \%$ ) and unlabelled $1 \mathrm{M} \mathrm{HCl}$ (two batches: $\delta^{18} \mathrm{O}$ value of $-6.4 \% 0$ and $-7.1 \%$ ) was used ${ }^{49}$. Therefore, the soil, which was recovered from the $\mathrm{NaOH}$-EDTA step, was dried at $40^{\circ} \mathrm{C}$, milled to $<2 \mathrm{~mm}$ and divided into two equal parts. One part was extracted with ${ }^{18} \mathrm{O}$-labelled $1 \mathrm{M} \mathrm{HCl}$, the other part was extracted with unlabelled $1 \mathrm{M} \mathrm{HCl}$. The $\mathrm{NaOH}$-EDTA extract was freeze-dried and homogenised afterwards with a pestle and mortar. The freeze-dried material from selected samples was used for the determination of the $\delta^{18} \mathrm{O}_{\mathrm{P}}$ of the inorganic $\mathrm{P}$ as described by Tamburini et al. ${ }^{37}$. Inorganic $\mathrm{P}(\mathrm{Pi})$ concentrations for all extracts were determined colourimetrically on an Aquachem 250 analyser using a molybdenum blue reaction ${ }^{50}$, while total $\mathrm{P}$ in the $\mathrm{NaOH}$-EDTA extracts was analysed on the same equipment following oxidation with potassium persulphate. The concentration of organic $\mathrm{P}\left(\mathrm{P}_{\text {org }}\right)$ in the $\mathrm{NaOH}$-EDTA (afterwards referred to as NaOH-EDTA $\mathrm{P}_{\text {org }}$ ) extracts was calculated as the difference between total $\mathrm{P}$ and inorganic $\mathrm{P}$ concentrations in the NaOH-EDTA extracts. The $\mathrm{Pi}$ in the $\mathrm{NaOH}$-EDTA is afterwards referred to as $\mathrm{NaOH}$-EDTA Pi. Microbial P was calculated as difference between resin and hexanol $\mathrm{P}$ and corrected for $\mathrm{P}$ adsorption ${ }^{51}$.

Soil water extraction. Soil water was extracted cryogenically from sealed, pre-frozen samples at the NERC Isotope Geoscience Facility, British Geological Survey, UK, following the method described by West et al..$^{52}$. Frozen samples (approximately $10 \mathrm{~g}$ frozen soil) were unsealed and placed in a U-shaped vacuum tube (borosilicate glass), the sample containing side of which was immersed in liquid $\mathrm{N}$ to ensure complete freezing and no loss of soil water. The $U$ tube was then evacuated to a pressure of $<10^{-2} \mathrm{mbar}$, removing all residual atmospherics. Once under stable vacuum, the $U$ tube was sealed, removed from the vacuum line and the sample side of the tube placed in a furnace at $100^{\circ} \mathrm{C}$. Soil water collection was achieved by immersing the opposite side of the glass U tube in liquid nitrogen, forcing evaporating soil water to condense and collect. This set up was maintained for $>1$ hour to ensure complete water transfer. Soil water was collected and stored refrigerated in $1.5 \mathrm{ml}$ vials with no headspace until isotope analysis.

Further soil analyses. Sieved and air-dried soil was used to determine the soil $\mathrm{pH}$ in water as described by Faithfull ${ }^{53}$. Total carbon (TC) and total nitrogen (TN), was determined using finely ground and air-dried soil, with an elemental analyser (NA2000, Carlo Erba Instruments, Milan, Italy). Total P in the soil was determined on air-dried and milled soil via aqua regia digestion ${ }^{54}$. Concentrations in the total $\mathrm{P}$ extracts were then determined by ICP-OES.

Oxygen isotopes in water and phosphate. Purification of the TCA, resin, microbial and $\mathrm{HCl} \mathrm{P}$ extracts and precipitation of silver phosphate $\left(\mathrm{Ag}_{3} \mathrm{PO}_{4}\right)$ followed the protocol by Tamburini et al. ${ }^{49}$. Modifications to this method were: $1 \mathrm{ml}$ of concentrated $\mathrm{H}_{2} \mathrm{SO}_{4}$ was added during the ammonium phosphomolybdate (APM) step during the purification of the TCA, resin and microbial P extracts to facilitate the precipitation of APM. Also a few silver nitrate $\left(\mathrm{AgNO}_{3}\right)$ crystals were added prior to precipitation of $\mathrm{Ag}_{3} \mathrm{PO}_{4}$ to ensure complete removal of $\mathrm{Cl}$ as silver chloride $(\mathrm{AgCl})$. Precipitated $\mathrm{AgCl}$ was filtered out using $0.2 \mu \mathrm{m}$ polycarbonate filters. Using size exclusion gel chromatography, selected freeze-dried and re-dissolved NaOH-EDTA extracts were separated in an organic and inorganic $\mathrm{P}$ fraction ${ }^{37}$. Only the inorganic $\mathrm{P}$ fraction of the $\mathrm{NaOH}-\mathrm{EDTA}$ extraction was purified as described above. Analysis of phosphate ${ }^{18} \mathrm{O}:{ }^{16} \mathrm{O}\left(\delta^{18} \mathrm{O}\right)$ was undertaken by weighing approximately $300 \mu \mathrm{g}$ of $\mathrm{Ag}_{3} \mathrm{PO}_{4}$ into a silver capsule to which a small amount of fine glassy carbon powder was added ${ }^{49}$. The sample was converted to carbon monoxide by dropping it into a thermal conversion elemental analyser (ThermoFinnigan, Germany) at $1400^{\circ} \mathrm{C}$, the resultant CO mixed with a helium carrier gas passes through a GC column into a Delta + XL mass spectrometer (ThermoFinnigan, Germany). $\delta^{18} \mathrm{O}_{\mathrm{P}}$ was calculated by comparison to internal $\mathrm{Ag}_{3} \mathrm{PO}_{4}$ laboratory standard, ALFA-1 (ALFA- $1=\delta^{18} \mathrm{O}$ VSMOW value of $14.2 \%$ ). In the absence of an international $\mathrm{Ag}_{3} \mathrm{PO}_{4}$ reference material, we derived this value for ALFA-1 by comparison to the $\mathrm{Ag}_{3} \mathrm{PO}_{4}$ standard 'B2207' (Elemental Microanalysis Ltd., England), which has been measured in an inter-laboratory comparison study to have a $\delta^{18} \mathrm{O}$ value of $21.7 \%$ versus VSMOW. Samples were run in triplicate, with a typical precision $\sigma \leq 0.3 \%$.

Soil water $\delta^{18} \mathrm{O}$ was determined on an Isoprime Aquaprep coupled to an Isoprime 100 dual-inlet mass spectrometer (Isoprime Ltd., Cheadle, England) through a process of headspace $\mathrm{CO}_{2}$ equilibration with water samples. The isotope ratios are reported as $\delta^{18} \mathrm{O}_{\mathrm{H} 2 \mathrm{O}}$ values versus VSMOW, based on comparison with laboratory standards calibrated against IAEA standards VSMOW and SLAP, with analytical precision typically $\sigma \leq 0.05 \%$. The theoretical equilibrium between $\mathrm{O}$ in soil water and $\mathrm{O}$ in phosphate was calculated for each depth and treatment using a modified version of the equation given by Chang and Blake ${ }^{22}: \delta^{18} \mathrm{O}_{\mathrm{P}}=-0.18 \mathrm{~T}+26.3+\delta^{18} \mathrm{O}_{\mathrm{H} 2 \mathrm{O}}$, where $\delta^{18} \mathrm{O}_{\mathrm{P}}$ is the stable oxygen isotope ratio of phosphate at equilibrium in $\%$, $\mathrm{T}$ is the temperature in degrees Celsius and $\delta^{18} \mathrm{O}_{\mathrm{H} 2 \mathrm{O}}$ is the stable oxygen isotope ratio of the soil water in \%o. The minimum and maximum soil temperatures in the 24 hours prior to the soil sample were used for calculating the equilibrium values as it can take up to 24 hours until the equilibrium is reached ${ }^{22}$. The microbial $\mathrm{P} \delta^{18} \mathrm{O}_{\mathrm{P}}$ was determined via mass balance using the concentrations of the resin, hexanol and microbial $\mathrm{P}$ and the $\delta^{18} \mathrm{O}_{\mathrm{P}}$ values of resin and hexanol $\mathrm{P}^{23}$.

Received: 5 September 2019; Accepted: 20 January 2020;

Published online: 07 February 2020 


\section{References}

1. The Crop Site. World Reserves of Phosphate Rock - Dynamic, Unfolding Story - The Crop Site. Better. Crop. Plant. Food 97, 18-20 (2013).

2. Sattari, S. Z., Bouwman, A. F., Martinez Rodriguez, R., Beusen, A. H. W. \& van Ittersum, M. K. Negative global phosphorus budgets challenge sustainable intensification of grasslands. Nat. Commun. 7 (2016).

3. Fay, P. A. et al. Grassland productivity limited by multiple nutrients. Nat. Plants 1, 15080 (2015).

4. Haygarth, P. M., Chapman, P. J., Jarvis, S. C. \& Smith, R. V. Phosphorus budgets for two contrasting grassland farming systems in the UK. Soil. Use Manag. 14, 160-167 (1998).

5. Arai, Y. \& Sparks, D. L. Phosphate reaction dynamics in soils and soil components: A multiscale approach. in Advances 94, 135-179 (Academic Press, 2007).

6. Richardson, A. E. et al. Plant and microbial strategies to improve the phosphorus efficiency of agriculture. Plant. Soil. 349, 121-156 (2011).

7. Lidbury, I. D. E. A. et al. The 'known' genetic potential for microbial communities to degrade organic phosphorus is reduced in lowpH soils. Microbiologyopen 6, e00474 (2017).

8. Scheffer, F. \& Schachtschabel, P. Lehrbuch der Bodenkunde: 100 Tabellen. (Enke, 1998).

9. Tian, D. \& Niu, S. A global analysis of soil acidification caused by nitrogen addition. Environ. Res. Lett. 10, 24019 (2015).

10. Slessarev, E. W. et al. Water balance creates a threshold in soil pH at the global scale. Nat. 540, 567 (2016).

11. Barrow, N. J. The effects of $\mathrm{pH}$ on phosphate uptake from the soil. Plant. Soil. 410, 401-410 (2016).

12. Simonsson, M. et al. Pools and solubility of soil phosphorus as affected by liming in long-term agricultural field experiments. Geoderma 315, 208-219 (2018).

13. Rothamsted Long-term Experiments. Rothamsted research: guide to the classical and other long-term experiments, datasets and sample archive (2018).

14. Crawley, M. J. et al. Determinants of species richness in the park grass experiment. Am. Nat. 165, 179-192 (2005).

15. Zhalnina, K. et al. Soil pH Determines Microbial Diversity and Composition in the Park Grass Experiment. Microb. Ecol. 69, 395-406 (2015).

16. Li, H. \& Jaisi, D. P. An isotope labeling technique to investigate atom exchange during phosphate sorption and desorption. Soil. Sci. Soc. Am. J. 79, 1340-1351 (2015).

17. Jaisi, D. P., Blake, R. E. \& Kukkadapu, R. K. Fractionation of oxygen isotopes in phosphate during its interactions with iron oxides. Geochim. Cosmochim. Acta 74, 1309-1319 (2010).

18. Jaisi, D. P. Stable isotope fractionations during reactive transport of phosphate in packed-bed sediment columns. J. Contam. Hydrol. 154, 10-19 (2013).

19. Blake, R. E. Biogeochemical cycling of phosphorus: Insights from oxygen isotope effects of phosphoenzymes. Am. J. Sci. 305, 596-620 (2005).

20. von Sperber, C., Kries, H., Tamburini, F., Bernasconi, S. M. \& Frossard, E. The effect of phosphomonoesterases on the oxygen isotope composition of phosphate. Geochim. Cosmochim. Acta 125, 519-527 (2014).

21. Liang, Y. \& Blake, R. E. Oxygen isotope signature of Pi regeneration from organic compounds by phosphomonoesterases and photooxidation. Geochim. Cosmochim. Acta 70, 3957-3969 (2006).

22. Chang, S. J. \& Blake, R. E. Precise calibration of equilibrium oxygen isotope fractionations between dissolved phosphate and water from 3 to $37^{\circ} \mathrm{C}$. Geochim. Cosmochim. Acta 150, 314-329 (2015).

23. Tamburini, F. et al. Oxygen isotopes unravel the role of microorganisms in phosphate cycling in soils. Environ. Sci. Technol. 46, 5956-5962 (2012).

24. Cassagne, N., Remaury, M., Gauquelin, T. \& Fabre, A. Forms and profile distribution of soil phosphorus in alpine Inceptisols and Spodosols (Pyrenees, France). Geoderma 95, 161-172 (2000).

25. Abdi, D., Cade-Menun, B. J., Ziadi, N. \& Parent, L.-É. Long-term impact of tillage practices and phosphorus fertilization on soil phosphorus forms as determined by $\mathrm{P}$ nuclear magnetic resonance spectroscopy. J. Environ. Qual. 43, 1431 (2014).

26. Crews, T. E. \& Brookes, P. C. Changes in soil phosphorus forms through time in perennial versus annual agroecosystems. Agric. Ecosyst. Environ. 184, 168-181 (2014).

27. Jobbágy, E. G. \& Jackson, R. B. The distribution of soil nutrients with depth: Global patterns and the imprint of plants. Biogeochemistry 53, 51-77 (2001).

28. Bauke, S. L. et al. Subsoil phosphorus is affected by fertilization regime in long-term agricultural experimental trials. Eur. J. Soil. Sci. 69, 103-112 (2018).

29. Kemmitt, S., Wright, D., Goulding, K. \& Jones, D. pH regulation of carbon and nitrogen dynamics in two agricultural soils. Soil. Biol. Biochem. 38, 898-911 (2006).

30. Halstead, R. L., Lapensee, J. M. \& Ivarson, K. C. Mineralization of soil organic phosphorus with particular reference to the effect of lime. Can. J. Soil. Sci. 43, 97-106 (1963).

31. Trasar-Cepeda, M. C., Carballas, T., Gil-Sotres, F. \& de Blas, E. Liming and the phosphatase activity and mineralization of phosphorus in an andic soil. Soil. Biol. Biochem. 23, 209-215 (1991).

32. Turner, B. L. \& Blackwell, M. S. A. Isolating the influence of $\mathrm{pH}$ on the amounts and forms of soil organic phosphorus. Eur. J. Soil. Sci. 64, 249-259 (2013).

33. Chater, M. \& Williams, R. J. B. The chemical composition of British agricultural liming materials. J. Agric. Sci. 82, 193-205 (1974).

34. Pfahler, V., Tamburini, F., Bernasconi, S. M. \& Frossard, E. A dual isotopic approach using radioactive phosphorus and the isotopic composition of oxygen associated to phosphorus to understand plant reaction to a change in P nutrition. Plant Methods 13 (2017).

35. Helfenstein, J. et al. Combining spectroscopic and isotopic techniques gives a dynamic view of phosphorus cycling in soil. Nat. Commun. 9, 3226 (2018).

36. Pfahler, V., Dürr-Auster, T., Tamburini, F., M. Bernasconi, S. \& Frossard, E. 18 O enrichment in phosphorus pools extracted from soybean leaves. N. Phytol. 197, 186-193 (2013).

37. Tamburini, F., Pistocchi, C., Helfenstein, J. \& Frossard, E. A method to analyse the isotopic composition of oxygen associated with organic phosphorus in soil and plant material. Eur. J. Soil. Sci. 69, 816-826 (2018).

38. Pistocchi, C. et al. Tracing the sources and cycling of phosphorus in river sediments using oxygen isotopes: Methodological adaptations and first results from a case study in France. Water Res. 111, 346-356 (2017).

39. Gustafsson, J. P. Modelling competitive anion adsorption on oxide minerals and an allophane-containing soil. Eur. J. Soil. Sci. 52, 639-653 (2001).

40. Devau, N., Cadre, E. L., Hinsinger, P., Jaillard, B. \& Gérard, F. Soil pH controls the environmental availability of phosphorus: Experimental and mechanistic modelling approaches. Appl. Geochem. 24, 2163-2174 (2009).

41. Tamburini, F., Pfahler, V., von Sperber, C., Frossard, E. \& Bernasconi, S. M. Oxygen Isotopes for Unraveling Phosphorus Transformations in the Soil-Plant System: A Review. Soil. Sci. Soc. Am. J. 78, 38-46 (2014).

42. Amelung, W. et al. The delta O-18 signatures of HCl-extractable soil phosphates: methodological challenges and evidence of the cycling of biological P in arable soil. Eur. J. Soil. Sci. 66, 965-972 (2015).

43. McDowell, R. W. \& Condron, L. M. Chemical nature and potential mobility of phosphorus in fertilized grassland soils. Nutr. Cycl. Agroecosystems 57, 225-233 (2000).

44. Silvertown, J. et al. The Park Grass Experiment 1856-2006: its contribution to ecology. J. Ecol. 94, 801-814 (2006). 
45. Avery, B. W. \& Catt, J. A. The soil at Rothamsted. (Lawes Agricultural Trust, 1995).

46. Kouno, K., Tuchiya, Y. \& Ando, T. Measurement of soil microbial biomass phosphorus by an anion exchange membrane method. Soil. Biol. Biochem. 27, 1353-1357 (1995).

47. Weiner, T. et al. A method for analyzing the $\delta 18 \mathrm{O}$ of resin-extractable soil inorganic phosphate. Rapid Commun. Mass. Spectrom. 25, 624-628 (2011).

48. Liebisch, F. et al. Seasonal dynamics and turnover of microbial phosphorus in a permanent grassland. Biol. Fertil. Soils 50, 465-475 (2014).

49. Tamburini, F., Bernasconi, S. M., Angert, A., Weiner, T. \& Frossard, E. A method for the analysis of the $\delta 18 \mathrm{O}$ of inorganic phosphate extracted from soils with HCl. Eur. J. Soil. Sci. 61, 1025-1032 (2010).

50. Murphy, J. \& Riley, J. P. A modified single solution method for the determination of phosphate in natural waters. Anal. Chim. Acta 27, 31-36 (1962).

51. Bünemann, E. K., Augstburger, S. \& Frossard, E. Dominance of either physicochemical or biological phosphorus cycling processes in temperate forest soils of contrasting phosphate availability. Soil. Biol. Biochem. 101, 85-95 (2016).

52. West, A. G., Patrickson, S. J. \& Ehleringer, J. R. Water extraction times for plant and soil materials used in stable isotope analysis. Rapid Commun. Mass. Spectrom. 20, 1317-1321 (2006).

53. Faithfull, N. T. Methods in agricultural chemical analysis: a practical handbook. (Cabi, 2002).

54. Hartley, T. N., Macdonald, A. J., McGrath, S. P. \& Zhao, F.-J. Historical arsenic contamination of soil due to long-term phosphate fertiliser applications. Environ. Pollut. 180, 259-264 (2013).

\section{Acknowledgements}

This work was supported by the 2015 Rothamsted Fellowship. We thank the Lawes Agricultural Trust and Rothamsted Research for access to samples from the Rothamsted Long-term Experiments and for data from the e-RA database. The Rothamsted Long-term Experiments National Capability (LTE-NC) is supported by the UKRI (UK Research and Innovation) BBSRC (Biotechnology and Biological Sciences Research Council, BBS/E/C/000I0320 and BBS/E/C/000I0330) and the Lawes Agricultural Trust. The authors thank the Natural Environment Research Council (NERC) for analytical support through the award of grant IP-1715-0517. We thank Steve Freeman for his help during soil sampling, the staff in the Computational and Analytical Sciences department of Rothamsted Research for help with the sample analyses, and the staff in the Analytical Unit for their help with the analytical sample analyses.

\section{Author contributions}

V.P., S.G., A.M. and M.S.A.B. designed the study, V.P. sampled the soils and vegetation, V.P. analyzed, calculated, and evaluated the data. A.C.S. measured the isotope values. V.P., S.G., M.S.A.B., A.C.S., F.T., A.M. and A.M. interpreted the results and wrote the manuscript.

\section{Competing interests}

The authors declare no competing interests.

\section{Additional information}

Correspondence and requests for materials should be addressed to V.P.

Reprints and permissions information is available at www.nature.com/reprints.

Publisher's note Springer Nature remains neutral with regard to jurisdictional claims in published maps and institutional affiliations.

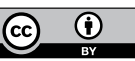

Open Access This article is licensed under a Creative Commons Attribution 4.0 International License, which permits use, sharing, adaptation, distribution and reproduction in any medium or format, as long as you give appropriate credit to the original author(s) and the source, provide a link to the Creative Commons license, and indicate if changes were made. The images or other third party material in this article are included in the article's Creative Commons license, unless indicated otherwise in a credit line to the material. If material is not included in the article's Creative Commons license and your intended use is not permitted by statutory regulation or exceeds the permitted use, you will need to obtain permission directly from the copyright holder. To view a copy of this license, visit http://creativecommons.org/licenses/by/4.0/.

(C) The Author(s) 2020 